
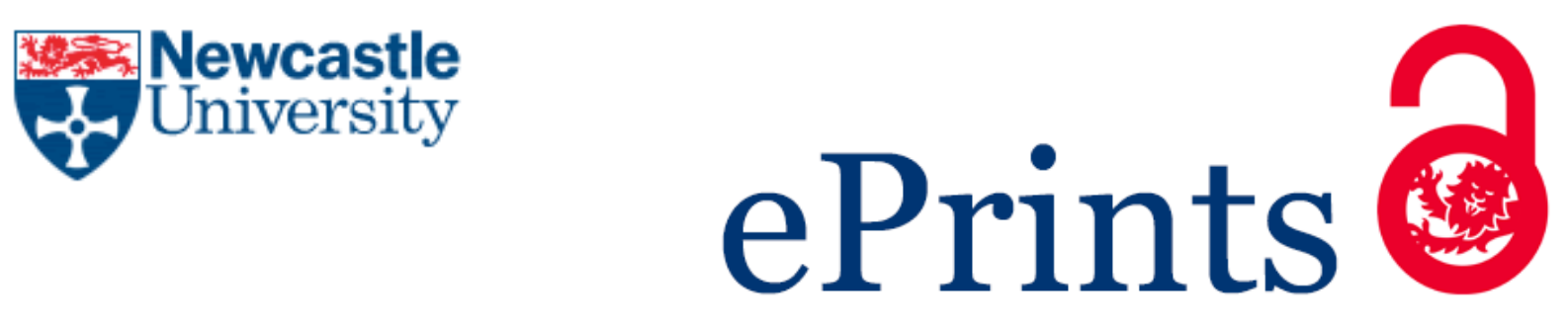

Chisholm A, Stachowitsch S. Everyday Matters in Global Private Security Supply Chains: A Feminist Global Political Economy Perspective on Gurkhas in Private Security. Globalizations 2017, DOI: 10.1080/14747731.2016.1155796

\title{
Copyright:
}

(C) 2016 Author(s). Published by Taylor \& Francis. This is an Open Access article distributed under the terms of the Creative Commons Attribution License (http://creativecommons.org/licenses/by/4.0/), which permits unrestricted use, distribution, and reproduction in any medium, provided the original work is properly cited.

DOI link to article:

http://dx.doi.org/10.1080/14747731.2016.1155796

Date deposited:

$16 / 05 / 2016$

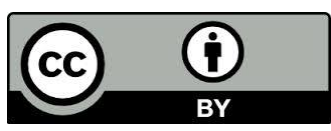

This work is licensed under a Creative Commons Attribution 4.0 International License 


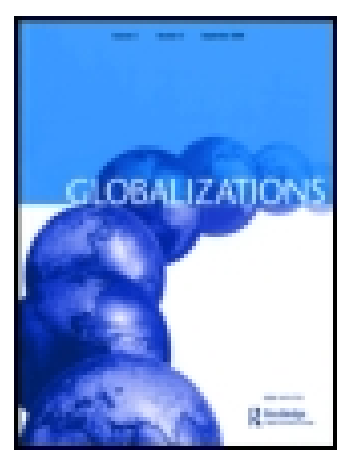

Globalizations

\section{Everyday Matters in Global Private Security Supply Chains: A Feminist Global Political Economy Perspective on Gurkhas in Private Security}

\section{Amanda Chisholm \& Saskia Stachowitsch}

To cite this article: Amanda Chisholm \& Saskia Stachowitsch (2016): Everyday Matters in Global Private Security Supply Chains: A Feminist Global Political Economy Perspective on Gurkhas in Private Security, Globalizations, DOI: 10.1080/14747731.2016.1155796

To link to this article: $h$ ttp://dx.doi.org/10.1080/14747731.2016.1155796

$$
\text { ( } 2016 \text { Author(s). Published by Taylor \& }
$$

曲 Published online: 16 Mar 2016.

Submit your article to this journal

Lll Article views: 257

Q View related articles ¿ك

View Crossmark data $\asymp$ 


\title{
Everyday Matters in Global Private Security Supply Chains: A Feminist Global Political Economy Perspective on Gurkhas in Private Security
}

\author{
AMANDA CHISHOLM* ${ }^{*}$ \& SASKIA STACHOWITSCH** \\ ${ }^{*}$ Newcastle University, Newcastle upon Tyne, UK \\ ** University of Vienna, Vienna, Austria
}

\begin{abstract}
In a case study of Nepalese Gurkhas working for Western private military and security companies (PMSCs), this article develops feminist global political economy understandings of global labour chains by exploring how the 'global market' and the 'everyday' interact in establishing private security as a gendered and racialised project. Current understandings of PMSCs, and global markets at large, tend to depoliticise these global and everyday interactions by conceptualising the 'everyday' as common, mundane, and subsequently banal. Such understandings, we argue, not only conceal the everyday within private security, but also reinforce a conceptual dualism that enables the security industry to function as a gendered and racialised project. To overcome this dualism, this article offers a theoretically informed notion of the everyday that dissolves the hegemonic separation into 'everyday' and 'global' levels of analysis. Drawing upon ethnography, semistructured interviews, and discourse analysis of PMSCs' websites, the analysis demonstrates how race, gender, and colonial histories constitute global supply chains for the security industry, rest upon and reinforce racialised and gendered migration patterns, and depend upon, as well as shape, the everyday lives and living of Gurkha men and women.
\end{abstract}

Keywords: Gurkhas, private security, feminist security studies, feminist global political economy, masculinity

\footnotetext{
Correspondence Addresses: Amanda Chisholm, Department of Politics, Newcastle University, Newcastle upon Tyne, UK. Email: amanda.chisholm@newcastle.ac.uk; Saskia Stachowitsch, Department of Political Science, University of Vienna, Vienna, Austria. Email: saskia.stachowitsch@univie.ac.at

(C) 2016 Author(s). Published by Taylor \& Francis

This is an Open Access article distributed under the terms of the Creative Commons Attribution License (http:// creativecommons.org/licenses/by/4.0/), which permits unrestricted use, distribution, and reproduction in any medium, provided the original work is properly cited.
} 


\section{A. Chisholm \& S. Stachowitsch}

\section{Introduction}

Over the last two decades, security provision has been subject to privatisation, marketisation, and commodification; processes that manifest in the outsourcing of state security functions to private actors. This has resulted in the growth of private military and security companies (PMSCs) which are increasingly overtaking airport security, logistical support to militaries, security training, static guarding, consultancy services, and close protection globally. Conventional research on this newly emerging private security industry has so far remained focused on strategic, legal, policy, and ethical implications of outsourcing and continues to be western-centric in analysis (Avant, 2005; Kinsey, 2006; Krahmann, 2008; Singer, 2003). Nevertheless, gender issues have found their way into different discourses in this research field.

While policy-oriented approaches promote the integration of a 'gender perspective' into the private security industry (Schultz \& Yeung, 2008), there is now also a growing body of critical research on the gendered and racialised structuring of private security (Eichler, 2015). Drawing upon insights from feminist security studies and feminist Global Political Economy (GPE), this scholarship highlights how the privatisation of (military) security masculinises and militarises perceptions of security, foreign policy, and the state and how interactions between the gendered state and the gendered market for force exacerbate inequalities and reaffirm masculinity as a privileged category in international politics (Eichler, 2013; Stachowitsch, 2013, 2015a, 2015b). Critical masculinity studies have been an important influence in this research field. By examining the gendered practices of contractors on the ground (Chisholm, 2010, 2014b; Higate, 2012) as well as PMSCs' marketing strategies (Joachim \& Schneiker, 2012, 2015), it was shown that the industry is not just a masculinised space but (re)produces a variety of hierarchically positioned masculinities.

The aforementioned gender research is important, yet, with the exception of Barker (2009), Ware (2010), Eichler (2014) and Chisholm (2014a, 2014b, 2015), has not yet systematically engaged with discussions of how global security labour chains constitute and are constituted by gendered and racialised relations. Such a gap results in missing the ways global South labourers and their communities are called upon to support the industry through paid and unpaid work. This article seeks to address this important lacuna by synthesising the critical gender research on PMSCs with a feminist GPE approach that is sensitive to everyday practices and experiences of labourers within formal and informal sectors of the economy. By engaging in feminist GPE analysis and drawing upon the Gurkha experience-men with a 200-year history with the British military and now actively contracted by PMSCs, we argue that private security reproduces gendered and racialised hierarchies through the industry's globalised recruitment strategies and associated labour migration patterns for security work. Importantly, we view global market relations and everyday practices as equally constitutive of these processes and, as such, we are able to show how gender and race operate to simultaneously locate those marked by the 'Gurkha' identity in a position of privilege, providing opportunities for economic advancement, and in exploitative and vulnerable relations of disadvantage. Such analysis also expands the focus beyond the men who are recruited into private security and offers conceptual space to engage with the potential effects on the communities targeted by PMSCs' recruitment. This provides a fuller picture of how the commodification and marketisation of formerly public goods such as security rest upon the constructed separation between the global market sphere and the patterns of everyday life-a separation which ultimately obscures and thereby reinforces global power relations within the security market. 


\section{Bringing Feminist Political Economy Perspectives on the 'Market' and the 'Everyday' to Gendered Debates on PMSCs}

Feminist political economy analyses enable a more sophisticated understanding of power relations in the security industry than conventional approaches through their critical conceptualisation of 'markets', which they view not as 'neutral' spaces, but as depending on gendered, classed, and racialised inequalities (Elias, 2005; Skeggs, 2004; Tsing, 2008). Such scholarship highlights the relationships, biases, and beliefs of participants in the market that constitute value in commodity and labour and determine whose labour gets revealed and whose gets silenced (Skeggs, 2004). From this perspective, gender and race underpin hierarchical structures/systems in the legitimisation and naturalisation of differences in labour values and divisions of labour. Such legitimation and naturalisation practices are observed in the broader 'feminisation of labour' occurring in global markets, a practice of devaluing a person or group rendering them marginalised and silenced and compliant to masculinised authorities (Enloe, 2007). Feminisation of labour appears necessary within the increasingly neo-liberalising world that is founded upon crisis prone economies and flexible service orientated labour chains (Bhattacharyya, 2011; Peterson, 2010). Such changes in labour affect men and women. Because feminisation of labour is a process by which men and women are naturalised into particular labour markets and skill sets, this necessarily means that their ability to migrate for work depends upon their affiliations to local gender, racial, and class hierarchies. For men and women from the global South in particular, colonial histories and conceptions of race interplay with neo-liberal practices to shape their migration experiences (Phillips, 2011). These processes also pertain to global South labourers in the security industry, as the Gurkha case study reveals.

Furthermore, feminist approaches challenge traditional understandings of global markets by 'emphasizing the role of everyday social relations, actions, and the perspectives of nonelite groups and actors in the making of the global political economy' (Elias, 2010, p. 603). Empirically, this focus on the 'everyday' has highlighted the relevance of socially reproductive labour, largely assumed by women, as central to market functions (Bakker \& Silvey, 2008). This understanding enables us to shed light on women's role for the security market in the context of global labour chains_-informing and supporting the ways in which men migrate and take on security labour.

Cynthia Enloe's question 'Where are the women?' (Enloe, 1989, p. 7) has contributed to theorising the everyday by understanding the personal as both political and international. However, locating women and the everyday has been notably missing from the private security literature. This is due to the fact that, upon first sight, the security industry appears to be a bastion for men and masculinities, where particular versions of white western men are privileged. Yet, feminist approaches in international relations have taught us to go beyond superficial observations and reveal the women who are more indirectly affected and have been made invisible in the power spheres of international politics and global security. Engaging in the GPE of security opens up space to locate women and women's labour within the private security enterprise.

Feminist political economy scholarship has not just addressed the 'woman question' by looking at the 'everyday dimensions' in and of the global. Rather, it has transgressed traditional borders between productive/reproductive labour and between the global and the everyday, and shown how these gendered dualisms are constructed and upheld through economic theory and practice. Yet, the 'everyday' which has implicitly or explicitly informed feminist accounts, as well as other critical approaches to political economy, has been 'un- or undertheorised' and frequently used as a descriptive rather than an analytical tool (Davies, 2016). Matt Davies' interventions (2006) are 


\section{A. Chisholm \& S. Stachowitsch}

useful here because his work emphasises the historical process by which the separation between the 'everyday' and the 'global' comes into existence in the first place (p. 225).

Following Lefebvre (1991, 2002, 2005), Davies conceptualises the everyday as a 'residue' as activities labelled productive or market-related are becoming specialised and leave the household. ${ }^{1}$ He further argues that the very notion of the everyday is a product of 'capitalist modernity ... transform[ing] daily life to fit its patterns and needs' (Davies, 2006, p. 220). This process is intertwined with the (gendered) separation and hierarchisation between production and reproduction as well as waged and unwaged labour. Thus, analyses of the everyday should overcome the conception of '[s]ocial life ... in terms of its levels', because 'such an ahistorical conception reifies everyday life as a realm separate from the global' (Davies, 2006, p. 230, emphasis in original). Davies and Niemann (2002) further claim that, through creating and upholding this separation, International Relations (IR) and International Political Economy (IPE) theory serve as a 'mystification of global relations' (p. 561) when they define their subject areas in terms of political and economic elites and powerful institutions (p. 559).

This logic of separation is also shaped by colonisation as it locates the banal, reproductive everydayness with the colonised and the abstract rationality of IR with the metropolis (Davies, 2016). This construction can be disrupted not only by 'bringing in' the everyday, but by critiquing the idea of a distinct everyday level itself, which in turn serves as a critique of IPE as a whole (Davies, 2016). Davies' theorising recalls Cynthia Enloe's work on integrating the marginal into our understanding of IR (Enloe, 1989) as well as Ann Tickner's (1992) critique of the 'levels of analysis' (individual-state-international system) in neo-realist IR theory.

By connecting security markets to feminist GPE conceptualisations of the market and a theoretically informed critique of the everyday, we consider private security as constituted through relations that are embedded in particular notions of race and gender through which people bring life, give purpose, and apply meaning to markets (Peterson, 2010). In doing so, we view the structuring of security labour markets and the everyday practices of security labourers as two sides of the same phenomenon. Hence, our study of the Gurkha does not only show that the everyday is important, but that it is constitutive of global labour relations and how we understand them. The everyday of Gurkhas' and their families' lives makes the politics of global recruitment in private security possible. This analysis widens the perspective to include not only the security contractors themselves, but also the feminised/demeaned and silenced labour on which security assemblages depend. It addresses the various ways in which neoliberal security practices have been both particular and global in transforming gender and racial relations through the industry's recruitment strategies, its reliance upon global South migrant workers, and the families these migrants leave behind.

Gender and race, we argue, are apparent as organising principles of market relations on the global as well as the everyday scale. In our use of discourse analysis and ethnographic observations, we show the ways in which the everyday is informative of which security labour chains are possible and preferred. This entails not spatially removing the everyday from the international or solely locating it with the communities left behind (and particularly with the women of these communities). Rather we aim to challenge the colonial logic, which situates the mundane with those on the periphery, as well as the gendered logic that associates women with the reproductive.

\section{Methods}

To dissolve the conceptual boundaries between the global and the everyday in the context of private security, we analyse PMSCs websites and draw upon previous semi-structured 
interviews with Gurkha contractors and their western managements in the context of global labour markets and migratory movements.

The interviews showcase how individual actors within the market establish and sustain these labour chains. Interviews and ethnographic observations of Gurkha families and communities in Pokhara, Nepal were conducted by Amanda Chisholm during a two-month fieldwork trip in 2010. Further, we did an analysis of four PMSC websites that specifically market Gurkha labour. These companies are the key providers of Gurkhas for armed security in Afghanistan and Iraq (FSI WorldWide and IDG Security) and for unarmed security in non-hostile environments and training services (Everest Security Services and G4S Gurkha Security Services). The websites were analysed through a discourse-analytical reading of texts and images used to describe Gurkhas.

Qualitative in-depth interviews in individualised and focus group format were conducted with 18 Nepalese Gurkha in Afghanistan and Nepal between 2008 and 2010. All interviewees had previously worked with the British and Indian military or the Singaporean police for time spans between a few months to many years. All had homes and families in Nepal; many had children attending western universities. Interviews shed light on how contractors made sense of their experiences and how they understood and negotiated their own positions within PMSCs. Furthermore, four country managers and/or owners of security companies as well as three local recruitment and marketing agents who contract Gurkha services internationally were interviewed to capture how their perceptions of Gurkha influence recruiting and hiring practices.

\section{Globalised 'Martial Race': Recruiting the Gendered and Racialised Security Worker}

Private security is a global business. By way of example, Group 4 Security, the largest PMSC, has over 630,000 employees and operates in over 110 countries. Such employment figures make it the second to Walmart, as the world's largest global employer (Pingeot, 2012, p. 11). PMSCs are independent from national military labour markets and thus do not need to recruit from the workforce available in a given state territory. As a result, recruitment is globalised with the aim of reducing labour costs and organised against the backdrop of global structures of inequalities and colonial legacies linking PMSCs' host countries to their recruitment sites in the global South (Barker, 2009; Chisholm, 2014b; Eichler, 2013). Such global labour chains for the security market take on a racial and gendered dimension. Personnel for high security operations involving technical and consultancy expertise are generally recruited from Western countries and men with formal special military or police training perform these roles. Alternatively, men from the global South generally perform static guarding and convoy protection roles.

In the case of UK companies who recruit third country nationals (TCNs) security contractors from sites and communities in the global South, they privilege those deemed 'martial' - an imagination that has deep roots, practised during colonial times to sustain a racial hierarchy amongst colonial armies (Caplan, 1995; Enloe, 1980; Streets, 2004). While the colonial practices of categorising and identifying martial race fell out of favour for its overt racism, the communities that were founded upon these colonial identities persist in many ways (Chisholm, 2014a, 2016). With reference to security markets, applications of 'martial' logics underpin global South recruitment. As such, this security labour disproportionately goes to men recognised as martial through joint western military training-those being men identified as Gurkhas, Fijians, and various African nationalities. Subsequently, the dominant recruitment sites for global South security contractors are Nepal, Uganda, Kenya, and Fiji. 


\section{A. Chisholm \& S. Stachowitsch}

The distinction between global South and western security contractors is sustained through appealing to professional versus natural labourer binaries (Chisholm, 2014a, 2015, 2016). The image of the Western contractor invokes professionalism and acquired military qualifications, while the global South labourer is constructed as possessing 'natural' or 'raw' talent that needs to be 'sanitised' through western training (Chisholm, 2016; Joachim \& Schneiker, 2015). These distinctions between western and global South security labourers also justify and sustain material inequalities and differences in labour value.

By paying attention to the role of gender and race in the valorisation of labour, it becomes evident that private security markets feminise and racialise men from the global South to secure cheap labour. In this context, PMSCs do what Elias (2005) has shown multinational companies in the global South to do: they build on and reify local structures of inequalities by 'consolidat[ing] the connection between gender [and race] and specific skills and characteristics' (p. 97). Through their recruitment strategies, they construct the gendered and racialised identities that enable labour exploitation and thereby mediate individuals' abilities to enter global labour chains. In the security sector, this is largely organised through the martial race concept which essentialises some men as natural warriors racially predestined for security work. In this regard, the construction of martial race by PMSCs is akin to the process by which, for example, Bangladeshi women's labour in the textile industry is constructed as natural because of their 'nimble fingers' (Hossain, Mathbor, \& Semenza, 2013), Filipina women are cast as 'naturally' suited for care work because of their cultural 'caring' characteristics (Kofman, 2004, p. 651), and Chinese rural migrant women are portrayed as 'easily manageable', hard-working labourers drawn upon to work in the 'industrial reserve army' (Pun, 2004, p. 15). In all these cases, 'naturalising' practices obscure the gendered and racialised politics, which rest upon the logic that economically and politically disenfranchised women are 'easier to be regulated and controlled' (Griffin, 2007, p. 726). This devaluation of women's labour also works through the dualism between skilled and unskilled labour, which constructs men's skills as learned/acquired and women's as embodied/naturalised (Kofman, 2004). Though these findings originally relate to women, they can also be applied to men from 'martial races' whose skills and knowledge are understood as embodied, that is, mediated through their belonging to a racialised community. Comparable to the 'naturalised' female care worker, their (learned) skills and qualifications are naturalised and thus devalued in market terms. Only the white security manager with background in western military training is perceived as having learned skills. 'Race' thus serves as a means to feminise some men's labour. And Western security companies play a crucial role in the constructions of the dualism between skilled/valued/masculinised and unskilled/devalued/feminised labour.

\section{Contextualising Gurkha Willingness: The Nepalese Remittance Economy}

While the Gurkha identity is rooted in colonial histories and reconstructed in emerging global security markets, its survival is also a consequence of Nepal's state economy which is based upon mass migration and foreign remittances and thus migrant work remains an important economic and livelihood practice (Brusle, 2008). The Nepalese government actively encourages foreign migration as a policy in relieving national poverty levels (Thieme \& Wyss, 2005). Statistics from the International Labour Organization (ILO, 2010) indicate that out of the 34 million people in Nepal, nearly 2 million are formally working outside the country; 200,000 people are leaving every year. This statistic appears to be on the rise as, according to a World Bank report, $57 \%$ of Nepalese households have at least one migrant abroad or a returnee (World Bank, 2011) 
and as of July 2011, unofficial government documents record 2.08 million Nepalese migrants leaving Nepal and India for work internationally (Sijapati, Limbu \& Khadka, 2011). ${ }^{2}$

Labour migration in Nepal has been occurring for well over 200 years, making migration an integral feature in many regional communities across the country (Gill, 2003). In 2004, 32\% of Nepalese households benefited from international remittances (Bontch-Osmoloviski, Glinskaya, \& Lokshin, 2010). These remittance patterns have been attributed to significantly affecting social-economic, demographic, and political relations within Nepal (Adhikari, Gurung, \& Seddon, 2002). In fact, foreign remittances make up 23.5\% of Nepal's GDP (Nepal National Human Rights Commission [NNHRC], 2012).

Migration patterns are regional and class-based. Migration outside Asia is not possible for many migrants as the associated financial costs for travel, visas, and administration and the education level requirements are out of reach for many families (Thieme \& Wyss, 2005, p. 63). Because of this, most migration is to India. Often this migration is unregulated and the unregulated access to international employment can increase opportunities for men and women and, at the same time, place them in vulnerable positions (Khadka, Limbu, \& Sijapati, 2011). This is in part because western companies rely upon their lower paid services, while these same companies do not have immediate access to global South labour pools (personal communication with Gurkha security company directors, May-September 2010). Instead most western companies depend upon in-country manpower agencies. Because labour migration levels are high in Nepal, local manpower agencies are big business in the country-there are 769 registered agencies (NNHRC, 2012, p. 29). While the Nepalese government attempts to regulate these agencies, growing anecdotal and documented evidence gathered through interviews and by groups such as Nepal's National Human Rights Commission suggest that some engage in illegal and ethically dubious practices.

\section{Privileging Gurkhas: Sustaining an Exclusive 'Subaltern' and 'Martial' Labour Chain}

The word Gurkha conjures up images of colonial warriors, stealth in their movements, fierce, brave, and loyal to the British (and by extension, the West). Both historic and contemporary writings about these men, found in popular books authored by former British Gurkha Officers, showcased on PMSC websites and within the larger western media, emphasise these men's colonial origins and their military pursuits on behalf of the British Empire. Importantly, these historical accounts of Gurkhas remain indebted to particular constructions of race and gender during British imperialism and are foundational in how we make sense of and come to know Gurkhas in contemporary private security practices.

Colonial discourses define Gurkha masculinities through their physical prowess and a 'can do attitude' in military operations (Streets, 2004, p. 77). They have been described as possessing 'superhuman abilities in battle' (Des Chene, 1991, p. 6), and 'the smartest and most European-like' soldiers in India (Gould, 1999, p. 108). The British continue to draw upon these colonial tropes of martial men with an unfettered commitment to Britain, which are illustrated in popular books, in Gurkha museums both in the UK and Nepal, and on private security websites which offer Gurkha security services. For example, IDG Security, a PMSC that specifically markets and recruits Gurkhas into security operations globally, describes these men as 'famed for their outstanding qualities of bravery, dedication, discipline, loyalty and integrity, to be your most effective guardians' (IDG Security Website, 5 August 2013). Such natural martial attributes of a particular global South labourer makes Gurkhas, and other men who are deemed 'martial', desirable over other global South labourers. 


\section{A. Chisholm \& S. Stachowitsch}

Gurkhas have migrated for military labour in the Sikh and then British India armies since the early nineteenth century. This history persists in contemporary military foreign recruitment with British and Indian militaries under the tripartite agreement recruiting 3000 Gurkhas every year for military service. After their service, many Gurkhas continue to work in a militarised field where their military skill sets can be used. Gurkhas' martial race and global reputation allow them to fill a niche role in security, including unarmed static guards in the Gulf States, state protection providers in Brunei and Malaysia, cruise line security, and actual security contractors in Iraq and Afghanistan. The numbers of Gurkhas in private security is not known but according to a representative of the Nepal's Ministry of Labour in 2010, 1198 Nepalese men were formally employed in Afghanistan (personal communication with former Ministry of Labour representative, May 2010). The two main manpower providers supplying Gurkhas to armed security markets internationally (FSI WorldWide and IDG Security) are directed by former British Gurkha officers. Their head offices are located outside Nepal, but they have dedicated staff, former Gurkhas with a personal connection to both directors, who recruit labour inside Nepal on their behalf. As of 2012, FSI WorldWide claimed to have 3000 Gurkhas employed globally, with IDG claiming 500 in Afghanistan alone. A representative for Nepal's Department of Foreign Employment unofficially estimated 3500-4000 Gurkhas to be working internationally; however, considering FSI WorldWide alone records that number on its payroll, the amount of Gurkhas seeking employment abroad is likely to be much higher.

On the websites that market Gurkha security labour, Gurkhas are described in relation to their military colonial histories with the British. This colonial relationship was also evident in interviews with various security managers in Afghanistan. As one representative of a security company stated, 'we know who Gurkhas are and their military capabilities'. It is this knowledge of Gurkhas that is reproduced on PMSC websites.

Everest Security, for example (Figure 1), draws on references to Gurkha colonial history, which is showcased with a black and white image of Gurkha soldiers. In describing their contractors, they draw reference to the martial attributes of honesty, bravery, and dedication. By

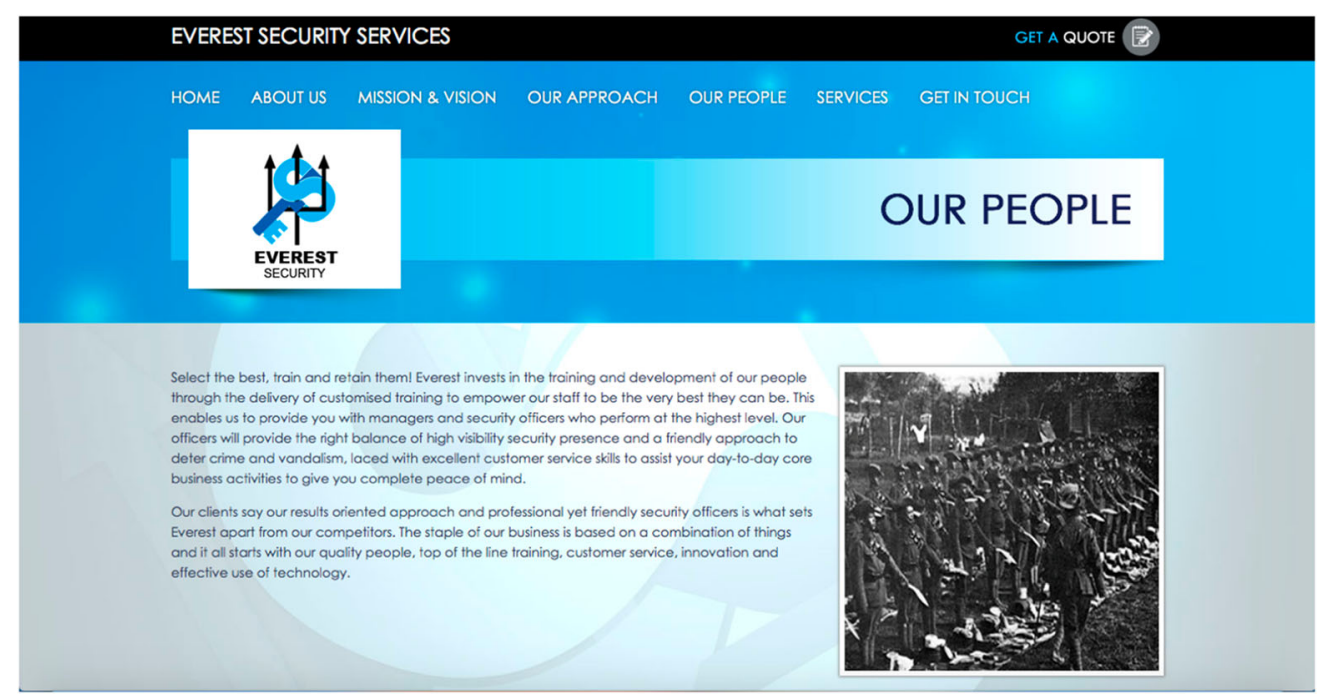

Figure 1. Everest Security Website accessed from http://everestgs.com/security/our_people.html. 
juxtaposing the colonial image and descriptions of Gurkhas with a corporate modern image at the top of the page, the company assures its audience that it is the selection of the proper staff-such as the Gurkhas with their proven military track record of service-that will ensure that the client's needs are met in contemporary security practices. Here the makers of these websites reinforce this everyday imagery of Gurkhas to advertise a special and exceptional global South labour force. Another firm (Gurkha Security Services) describes Gurkhas as people who are 'renowned for their bravery, trust, reliability, physical strength and courage'. Like Everest Security, this company draws a similar description of Gurkhas to reinforce why their security services are unique.

G4S Gurkha Security Services describes Gurkhas as reliable and trustworthy men. The consistent message on these websites is that these men carry timeless virtues of bravery, heartiness, and loyalty and are managed by white British national former Gurkha officers. The language used in these websites reproduces what Bhabha (1994) refers to as a colonial stereotype (pp. 94-95). The Gurkha is reproduced as an almost but not quite version of the British contractor. That is, the Gurkha's labour is always dependent upon its association with the fully developed, professional western contractor. Chisholm (2014b) has argued that such understandings of Gurkhas in relation to their western counterparts were also held by Gurkhas themselves.

These discourses demonstrate how Gurkha labour is constructed through their 'martial' culture. The concept of culture here works to explain the 'natural' differences between Gurkhas and westerners. It normalises Gurkhas into subservient role by claiming their 'natural' ability to deal with the mundaneness of guarding. These descriptions were reinforced during interviews with security directors. When asked what a Gurkha was, one of them used language that produces Gurkhas as 'culturally' suited for particular roles, and expats, because of their acquired skills in map reading and negotiations, as more suitable for managerial roles. This works to render some security labour less valuable and position Gurkhas in underpaid and underappreciated roles (Chisholm, 2015). The gendered distinctions between masculine, highly professional and feminised, natural skills sustain the racial divisions of labour between western and global South contractors. Yet, both reproduce these divisions of labour in everyday expressions of what it means for them to be security contractors.

\section{Finding and Critiquing the Everyday in Global Security Labour Chains}

The Gurkha case is to be placed within the context of the global security labour market, colonial power relations between labour exporting and importing countries, and the Nepalese remittance economy, which encourages gendered and racialised labour migration. Feminist GPE has taught us not to treat global and national economies, migratory movements, and labour markets as distant or abstract. Rather, they have shown how the everyday is constitutive of these phenomena and how it is deeply gendered. Following Davies' reading of Lefebvre (2006), the everyday is not to be understood as a mere 'level' of social reality which the security industry can build upon or where it has 'effects', but as structured by the conditions of the global political economy of security. The very distinction between the everyday and the global is a result of these conditions. The task at hand is thus to find and critique the everyday in global security labour chains to better understand how they reproduce gendered and racialised inequalities.

First, the everyday provides the individual motivation for participating in global security labour chains as well as the collective setting that enables it. Additionally, the discourses detailed above draw upon the individual experiences British men had with Gurkhas. This everyday colonial relationship is continually reproduced in a nostalgic and timeless way (Caplan, 
1995). In turn, this logic about who Gurkhas are and how they fit within the global labour chains of PMSCs are reinforced through the material reality of everyday life in Nepal as the primary reason why Gurkha men are willing to take on security labour. They tend to continue on with this kind of labour after their military service because of financial commitments, for example, in order for their children to pursue postgraduate education abroad (Chisholm, 2014b).

Gurkhas are amendable to such employment also because there is a deep-rooted cultural practice surrounding migrant work - one that depends on the support of those left behind. Labour migration is a part of life for Gurkha communities, one that the men and women appear to endorse (Des Chene, 1991; Thieme \& Wyss, 2005). Though the security industry tends to only actively recruit men, decisions to migrate are made in consultation with wives and, for the younger men, with fathers and mothers (Thieme \& Wyss, 2005). In most cases, women stay behind and take on subsistence, domestic and agricultural labour as Gurkha migration is long term (two years plus). They enable male migration by contributing to the financial costs through formal and informal labour and by taking over responsibility for family finances and businesses. The gendered migration pattern of men leaving for security work abroad and women staying behind is further solidified by legal restrictions and social stigma to women's independent migration. Hence, the private security industry depends on gendered power relations within these communities and on women and their paid and unpaid labour to support men's migration financially, organisationally, and emotionally. The industry is thus complicit with patriarchal values in their recruitment sites and, in the case of the Gurkha, the Nepalese state economy, which depends on remittances and therefore needs women to enable male labour migration.

Second, the global political economy of security shapes everyday experiences of Gurkhas within global labour chains. The Gurkha label legitimises inclusion in and exclusion from security labour markets. Whether someone is defined as Gurkha deeply affects his choices. The security market within Nepal is almost exclusively geared towards recruitment of these men, limiting large proportions of other Nepalese men and women's potential to access this market. It is through the everyday that this 'martial' identity is articulated and reconstructed in line with the needs of modern security markets. It is a product of everyday practices with which Gurkha as well as recruitment agents and Western managements regulate access to this market. According to interviews with security company directors, men who are deemed 'martial' with western military experience are seen as preferable over other global South labourers. For the most part, their employment options depend on Western security experts' construction of them as 'natural warriors'. At the same time, Gurkhas, and other TCN labourers, are actively involved in the racialising of their own labour to secure their privileged access to this labour market. In interviews, Gurkhas defined their subjectivities in terms of their ancestors' military operations and their own military training and martial histories. Yet, as Chisholm (2015) has indicated elsewhere, for many Gurkhas, their professionalism was linked to the military training received from the British. But Gurkhas also define themselves and their everyday as something that is beyond, and more than, the colonial relation (Chisholm, 2014b). They understand themselves as entrepreneurs and as men who make sacrifices in order to increase or at least offer different conditions of possibilities for their children.

While tensions and ambiguities in the colonial relations between Gurkhas and their white managers are beginning to emerge, at present PMSCs continue to offer comparatively lucrative work in relation to other employment. As such, the desire to garner these contracts is highly competitive. Overall, Gurkhas' colonial relations with the British, Indian armies and the Sultan of Brunei and the Singaporean police has offered them unique access to military labour, afforded 
them economic and social mobility, and increasingly provided them more labour opportunities within the security industry. This has allowed them to challenge their traditional caste-based socioeconomic status and to significantly improve the communities in which they live (Caplan, 1995). Increasingly these communities are becoming more educated and able to procure land and homes.

Despite being privileged in their ability to access security markets, Gurkhas and TCNs in general face many forms of exploitation and extortion once working in the security industry. As described above, racialisation and feminisation are important strategies for devaluing and exploiting their labour. Practices of bonded and forced labour were raised throughout interviews with both Gurkhas and Gurkha security company owners. Like other global South labourers, Gurkhas are confronted with informal recruitment and employment practices because they depend on informal (and silenced) networks as well as largely unregulated Nepalese manpower agencies. During interviews, stories also surfaced of men being recruited and deployed overseas who were not Gurkhas. These men are subject to high levels of exploitation and extortion by the manpower agents in the promise of obtaining work abroad. Many had accumulative debts, were isolated from larger communities within their places of deployment, and were in country illegally having gained entry under a tourist (and not working) visa. Actual tracking of these practices within the industry, however, remains anecdotal.

The Gurkha identity further typecasts Gurkha in particular ways, which makes it difficult for them to find employment in other sectors (Che Singh, 2010). In interviews, most men felt that after leaving the military, other employment opportunities within Nepal were not open to them because they were not clever enough (lacking formal education) or because they belonged to the wrong caste and did not have the social capital to go into business or other areas.

In addition to these limitations on men's choices, the security industry restricts women's opportunities in these communities as well. This aspect has neither been considered in debates on private security nor in research on the implication of the Nepalese migration economy more broadly. In the Nepalese case, most microeconomic studies emphasise the role of migration and remittances in reducing poverty and inequality. The impact on 'household members "left behind" has received relatively little attention among economists' (Glinskaya \& Lokshin, 2009). Migration in Nepal, however, takes place within a social framework; it affects families, households, and communities and brings changes in the gender division of labour (Glinskaya \& Lokshin, 2009, p. 3). A World Bank report suggests that male migration generally increases women's workloads and hampers their labour market participation (Glinskaya \& Lokshin, 2009). Conway and Shrestha (2001) have explicitly explored the 'shadow life of a migrant's wife' as an unfortunate and desperate existence. Due to social stigmas assigned to women working outside the home and few employment opportunities, Gurkha wives often do not take on paid labour while their husbands are abroad. This can lend them to being isolated as children are often in boarding school within Nepal or studying at a western university. By building on and exploiting local and global inequalities, the globalised security industry thus affects local women's lives, for example, by changing women's roles in the household economy and their relationship to the labour market.

\section{Conclusion}

Synthesising the critical gender research on PMSCs with feminist GPE analysis and drawing upon the everyday experiences and representations of Gurkhas offers an example of how private security markets, like other global markets, follow a colonial gendered and racialised 
logic in the recruitment and procurement of global South labour. These practices play an important role in bringing these men to market and assigning value to their labour. Seeing security markets through a gendered GPE lens demonstrates how the security market relies on feminised and racialised labour of both men and women. It also shows that the global political economy of security is dependent on the everyday lives as lived by men and women from the global South and that it structures their everyday experiences in global labour chains in many ways. However, the everyday, as Davies (2006) reminds us, is not just 'out there', it is itself a product of capitalist reconstruction, made to fit the patterns of global and national economies. This process is highly gendered and racialised and as such deeply political. In the Gurkha case, the everyday is structured by the security industry's and the Nepalese state economy's needs. The gendered and racialised everyday enables the industry's sourcing strategies, as much as it is a product of these strategies and their interactions with colonial power relations and the national economy. Following Lefebvre (1991, 2002, 2005), the everyday is a 'residue' as activities labelled productive or market-related are becoming specialised and hence leave the household. Quite literally, in the Gurkha case, Gurkha men leaving their families to work in the global security industry produce the everyday of these communities. The everyday of those leaving and of those left behind is hence deeply structured by global power relations.

But the everyday is not just an empirical reality; it is also the result of a discursive process through which some aspects of social phenomena are defined as global and others as mundane. The construction of Gurkhas as martial race is such a discursive (gendered and racialised) reproduction of the everyday. It is a strategy through which these men's skills and qualifications are naturalised and thereby located in the everyday, rather than related to global processes, colonial histories, and the political economy of private security. The everyday of Gurkhas' martiality works to obscure the political and colonial background of PMSCs' recruitment.

The reconstruction of the everyday is also taking place in (critical) GPE and IR debates. In this context, the everyday itself is frequently feminised and racialised by associating it with the mundane, banal, peripheral, with local women and with communities on the global margins. A critique of global security regimes and the inequalities they entail can thus not stop at highlighting how the everyday is important for understanding these inequalities. It needs to reflect upon its own gendered and racialised practices when analysing and thereby creating the category of the everyday. While concealing the everyday in analyses of the global security market is a depoliticising move, upholding conceptual dualisms between the global and the everyday equally obscures and thereby reinforces global power relations.

\section{Acknowledgements}

The authors would like to thank Matt Davies, the editors of the special issue, and the anonymous reviewers for their comments on earlier versions of this article.

\section{Disclosure Statement}

No potential conflict of interest was reported by the authors.

\section{Funding}

Research for this article was partly funded by the Austrian Science Fund (FWF) [project number V291-G22]. 


\section{Notes}

1 For a critique of how Lefebvre failed to use the theoretical and transformative potential of gender in his conceptualisation of the everyday see Redden (2015).

2 These statistics are likely doubled when informal labour is considered (personal communication with representative of Ministry of Labour, May 2010).

\section{ORCID}

Amanda Chisholm (D) http://orcid.org/0000-0001-9008-2529

\section{References}

Adhikari, J., Gurung, G., \& Seddon, D. (2002). Foreign labour migration and remittance economy in Nepal. Critical Asian Studies, 34(1), 19-40.

Avant, D. D. (2005). The market for force: The consequences of privatizing security. Cambridge: Cambridge University Press.

Bakker, I., \& Silvey, R. (2008). Beyond states and markets: The challenges of social reproduction. Oxon: Routledge. Barker, I. V. (2009). (Re)Producing American soldiers in an age of empire. Politics and Gender, 5(2), 211-235.

Bhabha, H. K. (1994). The location of culture. London: Routledge.

Bhattacharyya, G. (2011). Will these emergencies never end? In R. S. Gill (Ed.), New femininities: Postfeminism, neoliberalism and subjectivity (pp. 306-319). London: Palgrave MacMillian.

Bontch-Osmoloviski, M., Glinskaya, E., \& Lokshin, M. (2010). Work-related migration and poverty reduction in Nepal. Review of Development Economics, 14(2), 323-332.

Brusle, T. (2008). Choosing a destination to work. Mountain Research and Development, 28(3/4), 240-247.

Caplan, L. (1995). Warrior gentlemen: 'Gurkhas' in the western imagination. Oxford: Berghahn Books.

Che Singh, K. G. (2010). Nepalese Gurkhas and their battle for equal rights. Race and Class, 52(2), 43-61.

Chisholm, A. (2010, February 17-20). Racialized representations of masculinities in private security: An ethnographic exploration of Gurkhas in Afghanistan. Paper presented at the International Studies Association Annual Convention, New Orleans.

Chisholm, A. (2014a). Marketing the security package: Colonial histories and neoliberal economies of private security. Security Dialogue, 45(4), 349-372.

Chisholm, A. (2014b). The silenced and indispensible: Gurkhas in private security. International Feminist Journal of Politics, 16(1), 26-47.

Chisholm, A. (2015). From warriors of empire to martial contractors: Reimagining Gurkhas in private security. In M. Eichler (Ed.), Gender in private security and global politics (pp. 95-113). New York, NY: Oxford University Press.

Chisholm, A. (2016). Postcoloniality and race in private security markets. In A. Leander \& R. Abrahamsen (Eds.), Routledge handbook of private security (pp. 177-186). London: Routledge.

Conway, D., \& Shrestha, S. A. (2001). The shadow life of a migrant's wife. In S. von der Heide \& T. Hoffan (Eds.), Aspects of migration and mobility in Nepal (pp. 153-178). Kathmandu: Ratna Pustak Bhandar.

Davies, M. (2006). Everyday life in the global political economy. In M. de Goede (Ed.), International political economy and poststructural politics (pp. 219-237). Basingstoke: Palgrave Macmillan.

Davies, M. (2016). Everyday life as critique. Revisiting the everyday in IPE with Henri Lefebvre and postcolonialism. International Political Sociology. doi:10.1093/ips/olv006

Davies, M., \& Niemann, M. (2002). The everyday spaces of global politics: Work, leisure, family. New Political Science, 24(4), 557-577.

Des Chene, M. (1991). Relics of empire: A cultural history of Gurkhas, 1815-1987. Stanford, CA: Stanford University.

Eichler, M. (2013). Gender and the privatization of security: Neoliberal transformation of the militarized gender order. Critical Studies on Security, 1(3), 311-325.

Eichler, M. (2014). Citizenship and the contracting out of military work: From national conscription to globalized recruitment. Citizenship Studies, 18(6/7), 600-614.

Eichler, M. (Ed.). (2015). Gender and private security in global politics. New York, NY: Oxford University Press.

Elias, J. (2005). Stitching-up the labour market. Recruitment, gender and ethnicity in the multinational firm. International Feminist Journal of Politics, 7(1), 90-111. 


\section{A. Chisholm \& S. Stachowitsch}

Elias, J. (2010). Locating the 'everyday' in International Political Economy: The roar which lies on the other side of silence. International Studies Review, 12, 603-609.

Enloe, C. (1980). Ethnic soldiers: State security in a divided society. Middlesex: Penguin Books.

Enloe, C. (1989). Bananas, beaches and bases. Making feminist sense of international relations. Berkeley: University of California Press.

Enloe, C. (2007). Globalization and militarism. Feminists make the link. Lanham, MD: Rowman \& Littlefield.

Gill, G. J. (2003). Seasonal labour migration in rural Nepal: A preliminary overview. London: Overseas Development Institute.

Glinskaya, E., \& Lokshin, M. (2009). The effect of male migration on employment patterns of women in Nepal. The World Bank Economic Review, 23(3), 481-507.

Gould, T. (1999). Imperial warriors: Britain and the Gurkhas. London: Granta Books.

Griffin, P. (2007). Refashioning IPE: What and how gender analysis teaches international (global) political economy. Review of International Political Economy, 14(4), 719-736.

Higate, P. (2012). 'Cowboys and professionals': The politics of identity work in private and military security company. Millennium: Journal of International Studies, 40(2), 321-341.

Hossain, M. I., Mathbor, G. M., \& Semenza, R. (2013). Feminization and labour vulnerability in global manufacturing industries: Does gender discourse matter? Asian Social Work and Policy Review, 7(3), 197-212.

International Labour Organization. (2010). Labour and social trends in Nepal 2010. National Planning Commission Government of Nepal, International Labour Office ILO Country Office for Nepal. Nepal: International Labour Organization.

Joachim, J., \& Schneiker, A. (2012). Of 'true professionals' and 'ethical hero warriors': A gender-discourse analysis of private military and security companies. Security Dialogue, 43(6), 495-512.

Joachim, J., \& Schneiker, A. (2015). The licence to exploit: PMSCs, masculinities and the third country national. In M. Eichler (Ed.), Gender and private security in global politics. (pp. 114-130). New York, NY: Oxford University Press.

Khadka, M., Limbu, A., \& Sijapati, B. (2011). Trafficking and forced Labour in Nepal: A review of the literature. Kathmandu: Himal Books.

Kinsey, C. (2006). Corporate soldiers and international security: The rise of private military companies. London: Routledge.

Kofman, E. (2004). Gendered global migrations. International Feminist Journal of Politics, 6(4), 643-665. doi:10.1080/ 1461674042000283408

Krahmann, E. (2008). Security: Collective good or commodity. European Journal of International Relations, 14(3), 379-404.

Lefebvre, H. (1991). Critique of everyday life, volume 1. London: Verso.

Lefebvre, H. (2002). Critique of everyday life, volume 2: Foundations for a sociology of the everyday. London: Verso.

Lefebvre, H. (2005). Critique of everyday life, volume 3: From modernity to modernism (Towards a Metaphilosophy of Daily Life). London: Verso.

National Human Rights Commission. (2012). Foreign labour migration and trafficking in persons in Nepal: A situational analysis (Report No. 108/149/2069). Harihar Bhawan: National Human Rights Commission Report SCNHRC Project.

Peterson, S. V. (2010). International/global economy. In L. Shepherd (Ed.), Gender matters in global politics: A feminist introduction to international relations (pp. 204-217). London: Routledge.

Phillips, N. (2011). Migration in the global political economy. In N. Phillips (Ed.), Migration in the global political economy (pp. 1-12). Boulder, CO: Lynne Rienner.

Pingeot, L. (2012). Dangerous partnerships. Private military and security companies and the UN. New York, NY: Global Policy Forum and Rosa Luxemburg Foundation.

Pun, N. (2004). Women workers and precarious employment in Shenzhen Special Economic Zone, China. Gender and Development, 12(2), 29-36. doi:10.1080/13552070412331332170

Redden, S. (2015, February 20). Exploring the connections between gender, everyday life, and potential transformation in Henri Lefebvre's critique of everyday life. Paper presented at the International Studies Association (ISA) Annual Convention, New Orleans, Louisiana.

Schultz, S., \& Yeung, C. (2008). Private military security companies and gender: Gender and security sector reform toolkit. Geneva: DCAF, OSCE/ODIHR, UN-INSTRAW.

Sijapati, B., Limbu, A., \& Khadka, M. (2011). Trafficking and forced labour in Nepal: A review of the literature. Kathmandu: Himal Books for Centre for the Study of Labour and Mobility. 
Singer, P. W. (2003). Corporate warriors: The rise of the privatized military industry. Ithaca, NY: Cornell University Press.

Skeggs, B. (2004). Class, self, culture. New York, NY: Routledge.

Stachowitsch, S. (2013). Military privatization and the remasculinization of the state: Making the link between outsourcing of military security and gendered state transformations. International Relations, 27(1), 74-94. doi:10.1177/ 0047117812470574

Stachowitsch, S. (2015a). The reconstruction of masculinities in global politics: Gendering strategies in the field of private security. Men and Masculinities, 18(3), 363-386.

Stachowitsch, S. (2015b). Military privatization as a gendered process: A case for integrating feminist international relations and feminist state theories. In M. Eichler (Ed.), Gender and private security in global politics (pp. 1936). New York, NY: Oxford University Press.

Streets, H. (2004). Martial races: The military, race and masculinity in British imperial culture, 1857-1914. Manchester: Manchester University Press.

Thieme, S., \& Wyss, S. (2005). Migration patterns and remittance transfer in Nepal: A case study of Sinik Basti in Western Nepal. International Migration, 43(5), 59-98.

Tickner, A. (1992). Gender in international relations. Feminist perspectives on achieving global security. New York, NY: Columbia University Press.

Tsing, A. (2008). Contingent commodities. Mobilizing labour in and beyond Southeast Asia forests. In J. Nevins \& L. Peluso (Eds.), Taking Southeast Asia to market. Commodities, nature and people in the neoliberal age (pp. 27-42). Ithaca, NY: Cornell University Press.

Ware, V. (2010). Whiteness in the glare of war. Soldiers, migrants and citizenship. Ethnicities, 10(3), 313-330.

World Bank. (2011). Large-scale migration and remittance in Nepal: Issues, challenges and opportunities. Kathmandu: Author.

Amanda Chisholm is a lecturer at Newcastle University in the Department of Politics. She teaches on critical international relations and postcolonial and feminist thought. Her research interests are located within the intersections of feminist global political economy and feminist security studies. Her work focuses on the privatisation of security and international military labour forces that support private military and security companies' global operations. Her recent publications include 'Marketing the Gurkha security package: Colonial histories and neo-liberal economies of private security' (Security Dialogue, 45(4), 2014); 'The silenced and indispensable: Gurkhas in private military and security companies' (International Feminist Journal of Politics, 16(1), 2014); and 'From warriors of empire to martial contractors: Reimagining Gurkhas in private security,' in Maya Eichler (Ed.), Gender and private security in global politics (Oxford University Press, 2015).

Saskia Stachowitsch is a research fellow and lecturer at the Department of Political Science, University of Vienna. Her research areas are gender and the military, private security, feminist international relations, security studies, and global political economy. Her publications include Gender ideologies and military labor markets in the US (Routledge, 2012); 'Military privatization and the remasculinization of the state: Making the link between the outsourcing of military security and gendered state transformations' (International Relations, 27(1), 2013); 'The reconstruction of masculinities in global politics: Gendering strategies in the field of private security' (Men and Masculinities, 6 October 2014); 'Military privatization as a gendered process: A case for integrating feminist international relations and feminist state theories,' in Maya Eichler (Ed.), Gender and private security in global politics (Oxford University Press, 2015). 